\title{
Review Essay: The Museum Boom in China and the State Efforts to Control History
}

Museums in China: The Politics of Representation after Mao. Marzia Varutti. Woodbridge, Suffolk, UK: Boydell and Brewer, 2014. 190 pp.

Exhibiting the Past: Historical Memory and the Politics of Museums in Postsocialist China. Kirk A. Denton. Honolulu: University of Hawai'i Press, 2014. $351 \mathrm{pp}$.

Museum Representations of Maoist China: From Cultural Revolution to Commie Kitsch. Amy Jane Barnes. Surrey, England: Ashgate, 2014. 253 pp.

Magnus Fiskesjö

Each of these three books on museums in both post-Maoist and Maoist China, all from 2014, deserves a wide readership - and they are sure to get one, for two reasons: they appear in the midst of a Chinese museum boom, as museums are being built or redesigned all over China in unprecedented numbers, both state-run and private. Moreover, these books also cast new light on how museums serve as a tool for shaping a hegemonic notion of Chinese identity and for guiding society in China, including especially through the selective remembrance of Chinese history that also underpins this identity formation.

I highly recommend all three books. The volumes by Marzia Varutti (Museums in China) and by Kirk Denton (Exhibiting the Past) are focused on developments in China itself, and I will come back to them later on.

Amy Jane Barnes' Museum Representations of Maoist China is about how museums in Britain represented China of the Mao era, and particularly the China of Mao's Cultural Revolution of 1966-76. As pointed out by Clint Twist (2014), collector of Maoist paraphernalia, despite its cover image of a post-Mao Chinese collection of Mao badges, Barnes' book is not about the current collecting of such items inside China. However, it does also cast much light on China itself, including in particular on how the Chinese state authorities in the Mao era sought to promote and shape the representation of China abroad.

Barnes' book is a great achievement. It recounts the history of the representation of China in Britain in the twentieth century, and how it was that Mao-era "folk art" and other propaganda art became acceptable and interesting in Britain in the 1960s and onwards, followed by today's transformation of these items into the new genre of "Commie kitsch." Barnes deploys an interesting concept, "mind shifts," to address such transformations of the influence of widely held (or "popular") perceptions that guide collecting and display. As she says, other concepts like the scientist's "paradigm shifts" or the succession of epistemes as suggested by Foucault are not quite good enough for analyzing ethnographically how such broad shifts occur in society. Here,

\footnotetext{
* This editorially reviewed contribution was accepted for publication in Museum Anthropology Review on February 11, 2015. The work is licensed under the Creative Commons Attribution 4.0 International License. To view a copy of this license, visit http://creativecommons.org/licenses/by/4.0/
} 
the main "shift" in focus is end of the influence of the formerly dominant notion of Chinese Classical art (itself first established in the West only by the nineteenth century) as something valuable, but that had come to an end with the Chinese empire so that there was nothing more to see (other than Chinese imitations of Western art, that is). The reign of this understanding came to an end as British people found interest and, for some, even revolutionary inspiration in Maoist propaganda posters and "folk art."

Barnes investigates how this shift occurred with the active help of Chinese government agencies eager to try to push the "soft power" of the Maoist regime. In time, these new Chinese genres became acceptable, thus a British "mind shift"-I like this concept, and I think it could be put to even more productive use with even more devoted attention to the social life of speech acts and other socially significant acts by authoritative figures, as explored in linguistic anthropology, and in the anthropology of the transformations of value systems and hierarchies. I think, for example, of Michael Thompson's Theory (1979), which analyzed precisely how artifacts are assigned and reassigned places in a value hierarchy that is sustained and also altered by social actors, especially by those with wealth and authority. Here, such value transformation occurs transnationally across the globe, in an interlinked British-Chinese social space.

Barnes (83) points to how the Chinese Party-State authorities in their tightly controlled society were able to select "foreign friends" to be allowed into the country and then manipulate and harness their staged experiences, for their own purposes. She provides an astutely assembled account of what these travellers were allowed to see. The author describes how visitors would "witness" certain things and then would contribute to promoting a new vision of China. Then, British cultural figures and museum curators began to represent Chinese social realism and other art as worthy and interesting, not least the purposefully rustique "peasant paintings from $\mathrm{Hu}$ County," which Barnes treat in their very own chapter. It is a fascinating story, and the book as a whole is a major contribution both to the study of the limited tunnel vision of China's "fellow travelers," of how they were handled, and of how they were able to contribute to a "mind shift" at home, bringing about the introduction of Maoist iconography into the halls of British museum collections and art exhibits.

I wonder about the significance of the Soviet legacy for the way Maoist authorities coached the representation of "their" China: what people could see, what it would mean, how it should be selectively represented. There is a fabulous recent book by Michael David-Fox, Showcasing the Great Experiment (2012), on the apparatus built up in the Soviet Union to show model sites to select sympathetic visitors coached to present an authorized picture to the outside. Importantly, as David-Fox mentions, the often willing, highly privileged outside visitors were in fact participants in a larger internal project of self-representation by way of exemplary models, itself an important means of regimenting Soviet society itself. One wonders how much of this SovietRussian machinery was borrowed by the Chinese Communists - or, in what ways their own use of willing outsiders and their own modes of propaganda manipulation of examples and models in mass media, as a crucial component in the regimentation of the Chinese people, may have built on earlier, imperial-era Chinese forms of guest ritual which likewise involved coercing and coaching outsiders, giving them a special role in a larger orchestration of power and authority, a "show" that organized imperial China as a whole. 
One aspect of developments inside Maoist China that could have been mentioned is the underground survival and practice of unauthorized forms of art in China even during the dictatorial Mao years, as recently showcased by authors like Wang Aihe (2010), and others. It went largely undiscovered by the visiting foreigners, who were tightly monitored and guided, so that the danger to any independent artist in contacting them would have been too great. This reminds us of the great contrast between Mao's China and today's market society, which is Barnes' next focus. Today, while all public (and private) space, including the Chinese internet, remains strictly policed, market transactions with wealthy Chinese and foreigners dealing in both traditional Chinese and modern-Western-inspired arts now dominate booming social arenas of art collecting, not least art that can pretend to be non-political.

Barnes' book concludes with the post-Mao era collecting and representation of Mao-era "Commie chic" and "Commie kitsch," which are part of this new, globalized consumption pattern. Still focused on the British and Western appropriation of such items (and not on their life in China-for which one can go to the new research by Lily Chumley [2014], and others), she discusses the common interpretation that since the 1960s, Mao badges and other paraphernalia, to those Westerners wearing and displaying them, had come to represent a vaguely chic "rebellious" image (in the manner of Che Guevara t-shirts) not necessarily bolstered by any profound knowledge of the actual historical realities. But she also (172) entertains the intriguing possibility that Westerners collect these as tokens of a vanquished (enemy) ideology. There may be something to this, though the suggestion may perhaps work better for post-Soviet and for post-"Che" paraphernalia. It does not work that well for Chinese objects since the Chinese PartyState is still there, having re-mythologized Mao after his death (comparable to how a refashioned Lenin was kept on in Soviet Russia). Mao's image is prominently displayed on Chinese currency bills; Mao-era statues of the "Chairman" himself still stand, all over the country. Moreover, newly made "lucky" Mao charms dangle from car mirrors. The ensemble of these post-Mao representations is much more than kitsch, or nostalgia. Mao remains as a potent, if divisive symbol, the presence of which reminds everyone of the unresolved issues in the state that Mao founded, reminding everyone of the limits to any challenge to state orthodoxy, even as this orthodoxy is itself redefined and revamped by the powers that be.

Denton's book (Exhibiting the Past) provides a map of this redefinition. He takes as his focus the sphere of history museums and other memorial sites that deal specifically with Chinese identity and memory, and which must conform to the limits set by officialdom in the new "reform era" since 1980 (that is, the current market-driven corporate state capitalism under continued Party rule). Denton surveys a wide range of museums and memorials, offering an early twenty-first century overview of the state of play of Chinese officialdom's selective memorializing, remembering, and organized forgetting.

Exhibiting the Past begins with a on the revamping of archaeology exhibits, which under Mao used to focus on illustrating class struggle but now instead emphasize and glorify "national origins," and artifacts of the imperial past as evidence for the genius of the Chinese nation. Denton provides an excellent account, including in-depth on that most official national history museum, the National Museum of China at Tiananmen Square - which was closed for years and years, while the re-casting was sorted out inside. 
Denton continues with a series of chapters on how Mao's era itself (that is, the first part of the People's Republic, 1949-76) is now refashioned, toned down and embedded within a redefined nationalistic history. This continues to prominently involve the Communist Party in its unwavering, self-appointed "leadership" (power) role, which Denton rightly emphasizes as hugely important. ${ }^{1}$ Chapters two through seven discuss a host of museums of national and local history, as well as museums specifically focused on the history of the Party itself and its revolution, on military museums and those museums and other sites that commemorate the Japanese invasion of China in the 1930s-40s (which, crucially, created the conditions for the Communist Party to take on and displace the previous Republican-era government), as well as memorial halls that commemorate heroes of the Party and its revolution and war.

Towards the end of the book is chapter ten, on "Red Tourism," today's large-scale tourism to select heroic sites, which is encouraged by the Party-State but is nowadays mainly handled and exploited by private interests that are entrepreneurial off-shoots from what was once a monolithic State, and which maintain all sorts of links to those in power. This chapter can be fruitfully read alongside chapter three, "Commodification and Nostalgia: Revolutionary history in the era of the market economy" - which also forms a direct continuity with Barnes' book in exploring how the sacralized heroes, martyrs, and leaders of the revolution are nowadays exploited entrepreneurially, for-profit. Denton also discusses how this builds on a certain continuity with the past, mainly in terms of traditional forms of glorifying martyrdom (98-103). It also extends to the time-honored imperial-era traditions of special shrines deifying generals leading imperial conquests, and similar dutiful servants of the empire.

One prime example of the pragmatic co-existence of Party and army hero memorials with today's thoroughly commercialized China is the museum-shrine devoted to the clandestine 1921 founding of the Communist Party, on a former back street in Shanghai. Today, ironically and significantly, it is located in the midst of a mall-like development area with pizza-parlors and movie-theatres showing the latest Chinese-approved Hollywood action films. Denton gives a useful account (92-94) of this memorial site and how it raises questions about the life of these sites in the context of about-face of the appearances of Chinese society from the stern, bare, and fearful Mao era to the ultra-commercialized street-life with bars and all in today's Shanghai. Indeed, when I visited there recently, I was struck by the unusually strict and severe attitude of the posted guards, who seemed dismayed with tourists not fully comprehending the demands of the sacral character of the place. As for the "Maosoleum" in Beijing, where Mao's dead body is on display, Denton's book defers to other authors and does not mention much about actual visitor behavior at the recently upgraded memorial sites for the heroes of the Party-State (such as in the "golden triangle" of the "red tourism" landscape of Hunan, birthplace of Mao and two more state leaders) that are discussed at length in some of the most fascinating parts of the entire book. But one can assume that a similar line is drawn there: there are limits to Chinese pragmatism, to curb any unruly behavior and define some sites as sacred, as opposed to mere museum displays.

Overall, this is a very rich book, a masterly survey of its chosen genre. I also note that some semi-independent sites presenting alternative views are not included. For example, while it is true - as Denton shows in his discussion of historical narratives and presentations - that Mao's Cultural Revolution is whitewashed or omitted in most museums, there are at least three museums around China (in Shanghai, Kunming, and in Heihe, Heilongjiang) devoted to the fate 
of the youth that Mao sent "down" to rural areas. They are created by members of the stillresentful millions of such people still alive, many of whom feel robbed by their youth and opportunities for education and more, and want to make sure that their fate is memorialized, too. Museums commemorating the atrocities and horrors of Mao's Cultural Revolution have also been set up in Hong Kong, and indeed is represented as a warning for posterity even on the mainland, through the massive collections of CR-era artifacts in the private-run Jianchuan Museum Cluster in Anren, near Chengdu (as documented in Collecting Insanity, a short film by Joshua Frank, 2014; it is briefly mentioned by Denton as a private history museum, 26). Varutti (199-120) spots another such Cultural Revolution private museum in Guangdong; and she also reminds us of the Virtual Museum of the Cultural Revolution (www.cnd.org.cr/english), which is based outside China (the Chinese government restricts or blocks access for Chinese people to much of the global cyberspace).

Where Denton's longer book is focused on sites and institutions explicitly involved in the shaping of historical memory, Marzia Varutti in her rather more concise book, Museums in China, instead seeks to provide an overview of Chinese museums as a whole. Varutti's book thus overlaps with Denton's, but is broader. (In bringing up discussions of Chinese exhibits visiting Britain, it also at times evokes Barnes' work on how Chinese is represented in the West).

As the subtitle of Varutti's work indicates, Museums in China: The Politics of Representation after Mao, offers an analysis of how Chinese museums today are involved in purposeful representation, above all of the new national identity "organically" founded on heritage, history, and glorious art - thus she concurs with Denton in observing how "the nation" now has displaced "class" (or class struggle) that dominated during Mao's time as the overarching guiding concept for all museum representation. A "mind shift," to be sure.

Varutti begins with an overview of the roots of the concept of "heritage" in modern China-of how the ancient ritual bronzes that were once symbols of power and prestige have now been assigned the new role of embodiments of national heritage. Here she asserts that heritage is translated into Chinese as wenwu, but I would argue that it is not quite as straightforward. Instead (and, actually even more interestingly), there is a tension between the Chinese term wenwu, which is a term taken from an earlier Classical Chinese compound and mainly refers to objects treated as heritage, and yichan, the contemporary term for heritage which is used to translate the international term and which has a more international flavor (and which may be derived, as with so many other terms in modern Chinese, from a modern Japanese formulation). ${ }^{2}$ This terminological quibble aside, I think Varutti's discussion well captures this same tension: that between older Chinese practices of collecting and appreciation of traditional artifacts and art forms, and the new idea, itself derived from Western modernity, that the nation has a heritage embodied in the objects left from the past.

Against this background, in chapter two Varutti paints a history of the emergence of modern Chinese museums since the late nineteenth century. In chapter three offers a very useful overview of the "New Actors in the Chinese Museum World," explaining who owns and who does what: including administrators, private entrepreneurs, donors, and audiences. 
Varutti then moves to a closer examination of the arrangement of objects in museums: how old and new Chinese aesthetics are brought together to serve the new purpose of representation, and how this includes omitting things, as well as particular techniques for presenting objects on display. Here, Varutti also borrows Greenblatt's concepts of "wonder" for the "singularized" (isolated) objects of Art, and "resonance" for when objects are used to evoke and support a narrative. This discussion is well anchored in current museological studies literature and it serves the book well as it moves on to take on a broad range of museum genres-especially, the art museums.

Art museums are a key genre that is growing rapidly in importance in China. Ostensibly nonideological, in China just as in the West (and elsewhere, already) art museums are increasingly positioned at the top of the value hierarchy of museums - this has to do with how art museums offer a boundless potential for prestige-enhancing investments by the wealthy. Such investment cast them as selfless devotees of higher values such as Art and Beauty, and (especially in the role of donors of rare and desirable objects) as dutiful sons and daughters of the Nation. In China as in the West, it is a way for the rich (and for the ultra-mega-rich, see below) to buy legitimacy, and displace any discussion of inequality by instead focusing on the worship of the nation's (and the world's) heritage of beauty. ${ }^{3}$ One stunning new such development (missed by both Varutti and Denton) is the Long Museum in Shanghai with two huge buildings, one in each main part of the city, mainly housing and displaying the private collections of one such power couple!

Some of the most successful portions of Varutti's book are precisely where she uses the concepts developed for the study of the use of aesthetics and display modes, to analyze "art" museumsas with the opulent Shanghai Museum (mainly in chapter four, "Museum Objects and the Chinese Nation," and in the subsequent chapter on how objects now are made to instantiate the nation). This is very productive, and could be taken even further: Even with her admirable discussions of museum architecture as another element of representation, in the case of the Shanghai Museum, Varutti makes but a brief reference (73) to the museum's mantra that its own curious design (in the shape of an ancient ritual bronze, handles and all) is a "cultural" echo of an ancient Chinese cosmology. But of course Varutti's own assertions about the new use of Classical aesthetics for modern purposes would permit us to see that while in the past, such correlations of the heavenly and the earthy mainly served to prop up and legitimize powerful kings and empires, and they have now been re-deployed here in new form, to legitimize the grandiose new nation, by casting it (in concrete "bronze") as continuous with the imperial past.

There follows two chapters that deal with the politics and the representation of the past, as in history museums, which are also placed in the historical context of imperial-era through Maoist and post-Maoist developments and conceptions. She also discusses how various "service" museums (for the police, the postal services, industries, etc.) do their part, in inculcating national identity and pride in China's national subjects, even children's museums where Chinese national heroes of science and other fields are held up as role models for the children (there are also some corners of fun).

Both Varutti and Denton devote considerable space at the end, to discussing how China's ethnic minorities are "curated" in the service of the broader program of Chinese museums, and almost entirely without their own input. This mobilization of the "internal other" takes place either in 
Chinese museums either devoted entirely to representing them, or in ethno-theme parks that are sometimes staffed by live, "authentic" ethnics, some real and some fake or pretend (see Denton, 207-210, on parks in Beijing and elsewhere; Varutti, chapters nine to ten, excellent on the ghostly and very curious ethno-mannequin section of the posh Shanghai Museum). ${ }^{4}$

Both authors make very welcome contributions to the study of this highly important phenomenon, which reveals how China's "internal others" are used for the sake of Chinese selfdefinition and self-making - mainly in the "Orientalist" mode, thus recognizing the exotic allure of the ethnics, while at the same time affirming a preconceived contrast with Chinese progress and modernity. ${ }^{5}$ It is true that the ethnics are mostly only allowed as props on the stage: they typically are not given much agency in these dramatizations of themselves as wards of the State, in need of Chinese tutelage. But there are also ethnic minority communities that attempt to jump on the bandwagon and take up the heritage-ization of culture by attempting to self-represent themselves in their own museums or even by turning their own homestead and village into a heritage tourism destination. I once came across a striking example of this in out-of-the-way Hunan, where ethnic Miao villagers had taken charge of the heritage-ization of their own village, so that they could charge tickets instead of Chinese entrepreneurs taking all the money away (as happens in many other places). Not only this, but they had also created a bona fide "Outdoor Military Museum," a small hillside museum where they showcased poisoned bamboo sticks, primitive cannons, and other weapons once deployed to confront the Qing dynasty imperial army (Fiskesjö n.d.)!

A final comment, perhaps to be expected from an anthropologist critic as myself, is that in each of the books the reader would have wanted to know more about what people actually do at these museum exhibits, theme parks, and other sites. Who are the visitors, how do they act on site, and how do they react to the exhibits? Do they "buy" the intended message, or sometimes reject it or subvert it? What are their thoughts? One would like to know much more.

Overall, there is a huge potential for Chinese museum studies - insofar as such fieldwork will be possible with the current tightening atmosphere in China, where censorship and control are being strengthened to prevent dissent or any challenges to official truths. Of course, museums even in democratic countries are often fiercely possessive and protective of their "image," and do not want outsiders to delve into the actual social life of their institution. To investigate them is not necessarily easy. In any case, as future China researchers hit the floor of the museum or take the Party hero shrine as ethnographic field site, they will want to have studied all the three books reviewed here. And as they enter this field of research, they also would do well to consider museums and related sites as part of a larger social landscape of meanings, as in Ren Hai's (2013) "themed spaces," and, specifically in terms of objects, as part of the general "system of objects" (Baudrillard 1996) in which the museumized object necessarily figures in a meaningful contrast with the non-museumized.

\section{Notes}

1. The Communist Party and its leaders are the ultimate arbiters of what is allowed for public circulation. Generally, the Party's self-appointed role as the locus of power and keeper of orthodoxy can best be compared to the role of the church in bygone systems of theocratic 
duopoly. Every level of government is supplemented by, subordinate to, and constantly supervised by the "church" (the Party secretaries at each level; as in every major company, museum, etc.), and, at the very top, it coincides with the Party (in the person of the Party General Secretary, who is simultaneously the country's President, and keeper of the faith).

2. Perhaps the most striking example of this tension is the name of the State Administration of Cultural Heritage, the central agency in charge of antiquities, which is known in Chinese as the "Wenwuju." This used to be translated as Bureau of Cultural Relics (from wenwu, which unmistakably signals an obsession with objects, and can be literally translated "cultural relics"). But in recent years, in order to adapt to the broader international conception of heritage (which can also refer to intangible heritage), the Chinese government changed the English translation, while keeping the Chinese name for internal consumption! (See Fiskesjö 2010).

3. I recently published a proposal for how to theorize this distinctly modern system, in general terms (Fiskesjö 2014a).

4. I have written on the several large-scale commercial ethno-theme parks in Shenzhen, in Southern China (Fiskesjö 2014b), where ethnic-minority Wa performers are recruited to impersonate both "traditional Wa," as well as Africans, New Zealand Maori, and American Indians, in order to satisfy the curiosity of domestic Chinese tourists.

5. On this notion of "orientalism" see Baumann and Gingrich 2004.

\section{References Cited}

Baudrillard, Jean

1996 The System of Objects. New York: Verso.

Baumann, Gerd, and Andre Gingrich, eds.

2004 Grammars of Identity/Alterity: A Structural Approach. Oxford: Berghahn Books.

Chumley, Lily H.

2014 "Post" and "Socialist": Avant-garde Nostalgias and State Traditions in Contemporary PRC Political Aesthetics. Presentation for the panel on Uses of the Past in Contemporary Asia, 20th IPPA Congress, Siem Reap, Cambodia, January 2014.

David-Fox, Michael

2012 Showcasing the Great Experiment: Cultural Diplomacy and Western Visitors to Soviet Union, 1921-1941. Oxford: Oxford University Press.

Fiskesjö, Magnus 
N.d. The Southern Great Wall. Unpublished MS.

2014a Art and Science as Competing Values in the Formation of the Museum of Far Eastern Antiquities. In Collectors, Collections, and Collecting the Arts of China: Histories and Challenges. Guolong Lai and Jason Steuber, eds. Pp. 67-98. Gainesville: University of Florida Press.

2014b Wa Grotesque: Headhunting Theme Parks and the Chinese Nostalgia for Primitive Contemporaries. Special issue, "Primitivist Tourism," Ethnos: Journal of Anthropology, August 20. DOI: 10.1080/00141844.2014.939100.

2010 The Politics of Cultural Heritage. In Reclaiming Chinese Society: The New Social Activism. Hsing You-tien and Lee Ching Kwan, eds. Pp. 225-245. London: Routledge.

Frank, Joshua

2014 Collecting Insanity. ChinaFile.com. http://www.chinafile.com/multimedia/video/ collecting-insanity, accessed January 20, 2015.

Ren, Hai

2013 The Middle Class in Neoliberal China: Governing Risk, Life-Building, and Themed Spaces. Routledge, New York.

Thompson, Michael

1979 Rubbish Theory: The Creation and Destruction of Value. New York: Oxford University Press.

Twist, Clint

2014 Review of Museum Representations of Maoist China: From Cultural Revolution to Commie Kitsch. Electronic document, http://www.maozhang.net/review1/4587033450, accessed January 20, 2015.

Wang Aihe, ed.

2010 Wuming (No Name) Painting Catalogue. Hong Kong: Hong Kong University Press.

Magnus Fiskesjö teaches anthropology and Asian studies at Cornell University. His research is mainly focused on the politics and histories of ethnic relations in China and Southeast Asia, as well as studies in Asian archaeology, and in critical museum studies and global heritage issues. His publications in these fields also build on his own experiences as director of the Museum of Far Eastern Antiquities, a museum of Asian archaeology and art located in Stockholm, Sweden, in the years 2000-2005. 
Museum Anthropology Review 9(1-2) Spring-Fall 2015

http://dx.doi.org/10.14434/mar.v9i1-2.19150 